\title{
A new deepwater lobster, Metanephrops serendipitus sp. nov. (Crustacea, Decapoda, Nephropidae), from lower Miocene of Meljski hrib (Maribor, Slovenia)
}

Una nueva langosta de aguas profundas, Metanephrops serendipitus sp. nov. (Crustacea, Decapoda, Nephropidae), del Mioceno inferior en Meljski hrib (Maribor, Eslovenia)

\author{
Rok Gašparič ${ }^{1,2, *}$, Dale Tshudy ${ }^{3}$, Tin-Yam Chan $^{4}$, Stjepan Ćorić $^{5}$
}

${ }^{1}$ Oertijdmuseum, Bosscheweg 80, 5293 WB Boxtel, Netherlands.

${ }^{2}$ Novi trg 59, 1241 Kamnik, Slovenia.

${ }^{3}$ Department of Geosciences, Edinboro University of Pennsylvania, Edinboro, Pennsylvania 16412, USA.

${ }^{4}$ Institute of Marine Biology and Center of Excellence for the Oceans, National Taiwan Ocean University, Keelung 202301, Taiwan.

${ }^{5}$ Geological Survey of Austria, Neulinggasse 38, 1030 Vienna, Austria.

* Corresponding author: (R. Gašparič) rok.gasparic@gmail.com

\section{ABSTRACT}

A new species of nephropid lobster, Metanephrops serendipitus sp. nov., is described from the lower Miocene (Ottnangian/Karpatian) in beds of Central Paratethys. Metanephrops serendipitus sp. nov. represents the first fossil representative of the genus from the northern hemisphere and thus extends its known palaeobiogeographical distribution. Additionally, the palaeoecology of the new species is discussed. Similar to extant species of Metanephrops, the fossil nephropid inhabited a fine-grained deep-sea environment, associated with frequent brittle stars.

Keywords: Decapoda, Nephropidae, south-central Europe, Central Paratethys, palaeobiogeography.
How to cite this article:

Gašparič, R., Tshudy, D., Chan, T.Y., Ćorić, S., 2021, A new deep-water lobster, Metanephrops serendipitus sp. nov. (Crustacea, Decapoda, Nephropidae), from lower Miocene of Meljski hrib (Maribor, Slovenia): Boletín de la Sociedad Geológica Mexicana, 73 (3), A240521. http://dx.doi.org/10.18268/ BSGM202lv73n3a240521

Manuscript received: March 27, 2021

Corrected manuscript received: May 24, 2021

Manuscript accepted: May 28, 2021
Peer Reviewing under the responsibility of Universidad Nacional Autónoma de México.

This is an open access article under the CC BY-NC-SA license(https://creativecommons.org/licenses/by-nc-sa/4.0/)

\section{RESUMEN}

Se describe una nueva especie de langosta nefrópida, Metanephrops serendipitus sp. nov., del Mioceno inferior hallada en los fondos marinos del Paratetis Central (Ottnangian / Karpatian). El ejemplar Metanephrops serendipitus sp. nov. representa el primer fósil del género procedente del hemisferio norte, por lo cual, también se agrega su distribución paleobiogeográfica. Además, se discute la paleoecología de esta nueva especie. Al igual que las especies existentes de Metanephrops, el fósil nefrópido habitaba un entorno de grano fino en aguas profundas y estaba asociado frecuentemente con estrellas de mar quebradizas.

Palabras clave: Decapoda, Nephropidae, centro-sur de Europa, Paratetis Central, paleobiogegrafía. 


\section{Introduction}

The clawed lobster genus Metanephrops Jenkins, 1972 is the most diverse one within the family Nephropidae, comprising 18 known extant and 3 fossil species (Tshudy et al., 2007; Chan et al., 2009; Tshudy and Chan, 2014). A fragmentary chela from the upper Eocene (Priabonian) of northern Italy (Garassino et al., 2003) tentatively assigned to Metanephrops sp. cannot be confirmed as belonging to this genus. The Pliocene fossil Metanephrops elongatus $\mathrm{Hu}$ and Tao, 1996 from Taiwan is a nomen dubium, but definitely not a Metanephrops (Tshudy and Chan, 2014). Metanephrops bears a strong morphological resemblance to Nephrops Leach, 1814, to which its members were previously assigned (Jenkins, 1972), although subsequent cladistic analyses show that this similarity is the result of morphological convergence (Tshudy et al., 2009).

Extant species of Metanephrops inhabit outer continental shelf and continental slope environments of a muddy bottom, with depth ranging between 50 and 994 meters (Chan, 1997). Most specimens were collected from depths greater than $150 \mathrm{~m}$ (Tshudy, 2003) from the Central and West Indo-Pacific between $35^{\circ} \mathrm{N}$ and $50^{\circ} \mathrm{S}$ latitude.

Metanephrops has a very patchy fossil record. Metanephrops taiwanicus $(\mathrm{Hu}, 1983)$ is the only extant species with a fossil record (Miocene and Recent from Taiwan; Tshudy and Chan, 2014). The oldest fossil occurrence is the Late Cretaceous M. rossensis Feldmann et al., 1993 from the Campanian of Antarctica. Another species described from shallow-water settings of Antarctica is $M$. jenkinsi Feldmann, 1989 from Late Cretaceous (Maastrichtian) to Paleocene strata.

Based on these data and a Pliocene species of M. motunauensis Jenkins, 1972 from New Zealand, Feldmann and Tshudy (1989) proposed that Metanephrops evolved in the high southern latitudes, in shallow water, and then radiated into lower latitude, deep-water settings. Molecular and morphological phylogenetic analyses supported this hypothesis and further suggested that these lobsters originated in the Antarctica, with a dispersal pattern associated to the breakup of the Southern Temperate Gondwana (Tshudy et al., 2007; Chan et al., 2009).

\section{Geology and stratigraphy of the locality}

A new specimen of nephropid lobster was found in yellowish marls that form a talus deposit below the Meljski hrib, near Maribor, Slovenia (46³3'38'”N, $15^{\circ} 40^{\prime} 33^{\prime \prime} \mathrm{E}$ ) (Figure 1). The Meljski hrib locality is known for fossil remains of Miocene invertebrates and fossil wood (Mikuž and Gašparič, 2014). The fossiliferous beds are located on the north-eastern outskirts of Maribor and form almost vertical cliffs of around $100 \mathrm{~m}$ height (Figure 2). The bottom part of the profile consists of dark grey siltstones and sandstones with rare macrofossils. Gašparič and Halasova (2015) have reported on finds of decapod crustaceans, including the crab, Styrioplax exiguous Glaessner, 1928, and chelae of callianassid ghost shrimps from this locality. Higher up, the light grey marls are harder and interbedded with frequent concretions layers of calcite crystals. These layers contain a rare macrofauna of bivalves and echinoids (Mikuž and Gašparič, 2014). The presented lobster specimen was found in the yellowish marls with mass mortality accumulations of brittle stars that originate from the hardly accessible top part of the cliffs.

These deposits structurally belong to the Pannonian Basin (Placer, 1999), and in the narrower sense to the tectonic unit of Slovenske gorice (Pavšič and Horvat, 2009). Miocene strata of Meljski hrib were deposited in the Mura Depression, in the western part of the Mura-Zala Basin of the Central Paratethys (Fodor et al., 2002). The Mura Depression, in the west, was part of the Slovenian Corridor, a seaway between the Central Paratethys and the Mediterranean (Rögl, 1999; Bartol et al., 2014).

The Central Paratethys underwent significant palaeogeographical changes during the Miocene. In the Early Miocene, extensional tectonic regime and synrift subsidence resulted in the forma- 
tion of deep elongated sedimentation basins (half-grabens) and a marine transgression via the Eastern Paratethys and Mediterranean (Pavšič and Horvat, 2009; Rifelj and Jelen, 2001). In the Middle Miocene, the Central Paratethys reached its maximum extent and consisted of an unbroken chain of epicontinental basins linked to the Mediterranean in the west and the Indo-Pacific in the east (Rögl, 1998; Kováč et al., 2007). By the late Middle Miocene, the situation had changed, the oceanic connections had closed and the Central Paratethys became reduced both in size and salinity (Bartol et al., 2014).

Marine deposits in this basin stretch across northeast Slovenia and have been dated from a lower Miocene (Burdigalian/Karpatian) to a middle Miocene (Serravallian/Sarmatian) age (Pavšič and Horvat, 2009; Žnidarčič and Mioč, 1989). Stratigraphy relies mostly on foraminifera (Rijavec, 1976; 1978) and in some cases on calcareous nannoplankton (Bartol, 2009; Bartol et al., 2013; Gašparič and Halasova, 2015).

Results of nannoplankton sampling of the matrix surrounding the nephropid lobster confirm its early Miocene age. The sample can be attribu- ted to NN4 biozone based on the co-occurrence of Sphenolithus heteromorphus Deflandre 1953 and Helicosphaera ampliaperta Bramlette and Wilcoxon 1967. This zone is defined as the interval between the first occurrence of S. heteromorphus (18 Ma) in the Burdigalian and the last occurrence of $H$. ampliaperta (14.9 Ma) in the Langhian (Young, 1998). Nannoplankton Zone NN4 spans three Paratethian regional stages: Ottnangian, Karpatian, and lower Badenian (Figure 3). The absence of Helicosphaera waltrans Theodoridis 1984, which was observed in the in lower Badenian (upper NN4 and lower NN5) of the Central Paratethys, points to the attribution of the investigated sample to the lower NN4 (Ottnangian/Karpatian).

\section{Material and methods}

The present study is based on a single specimen of a nephropid lobster that is preserved in a yellowish marl. The specimen was found in a talus below a steep cliff in two parts. Chelipeds were recovered from a block containing numerous specimens of undetermined brittle stars (Mikuž and Gašparič,

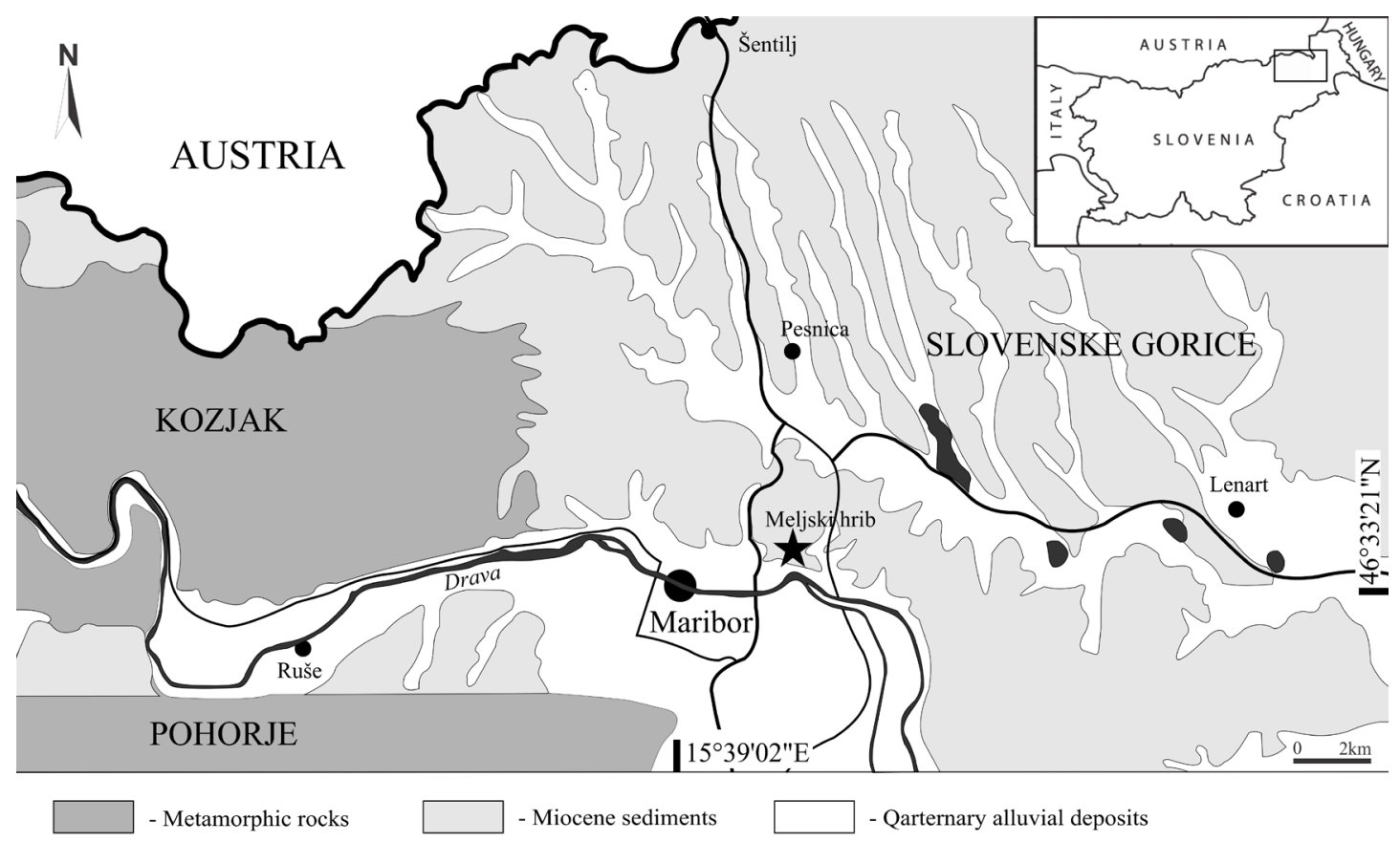


2014); the associated part of carapace was serendipitously recovered five years later in the same location. The specimen is preserved laterally compressed and fully articulated. The anterior part of the carapace does not lie fully parallel to the bedding plane and is slightly rotated. Specimen parts RGA/SMNH 2295, RGA/SMNH 2296, RGA/ SMNH 1590 and RGA/SMNH 1591 are registered as part of palaeontological collections at the Natural History Museum in Ljubljana (Slovenia).

The specimen was prepared and studied under a Leica EZ 4D stereomicroscope. Photographs were taken with a digital camera Nikon Z50 and whitened with ammonium chloride sublimate prior to photography in order to enhance details of the cuticle ornamentation. Photographs were subsequently developed in Photoshop CS6 to correct for light, contrast, colour and were inverted to approximate positive relief where needed.

Calcareous nannofossil smear slides were prepared using standard procedures described by Perch-Nielsen (1985) and examined under light microscope LEICA DMLP (crossed and parallel nicols) with 1000x magnification. For the biostratigraphical attribution, standard calcareous nannofossil zonation (NN) established by Martini (1971) was applied. For palaeoecological analyses 304, specimens were counted and statistically presented.

Abbreviations: RGA/SMNH - Slovenian Museum of Natural History, Ljubljana, Slovenia (R. Gašparič Collection).

\section{Systematic palaeontology}

\section{Class Malacostraca Latreille, 1802 \\ Order Decapoda Latreille, 1802 \\ Family Nephropidae Dana, 1852 \\ Genus Metanephrops Jenkins, 1972}

Type species: Nephrops japonicus TAPPARONECANEFri, 1873, by original designation.

Diagnosis: Carapace slightly compressed laterally; rostrum elongate with a single pair of

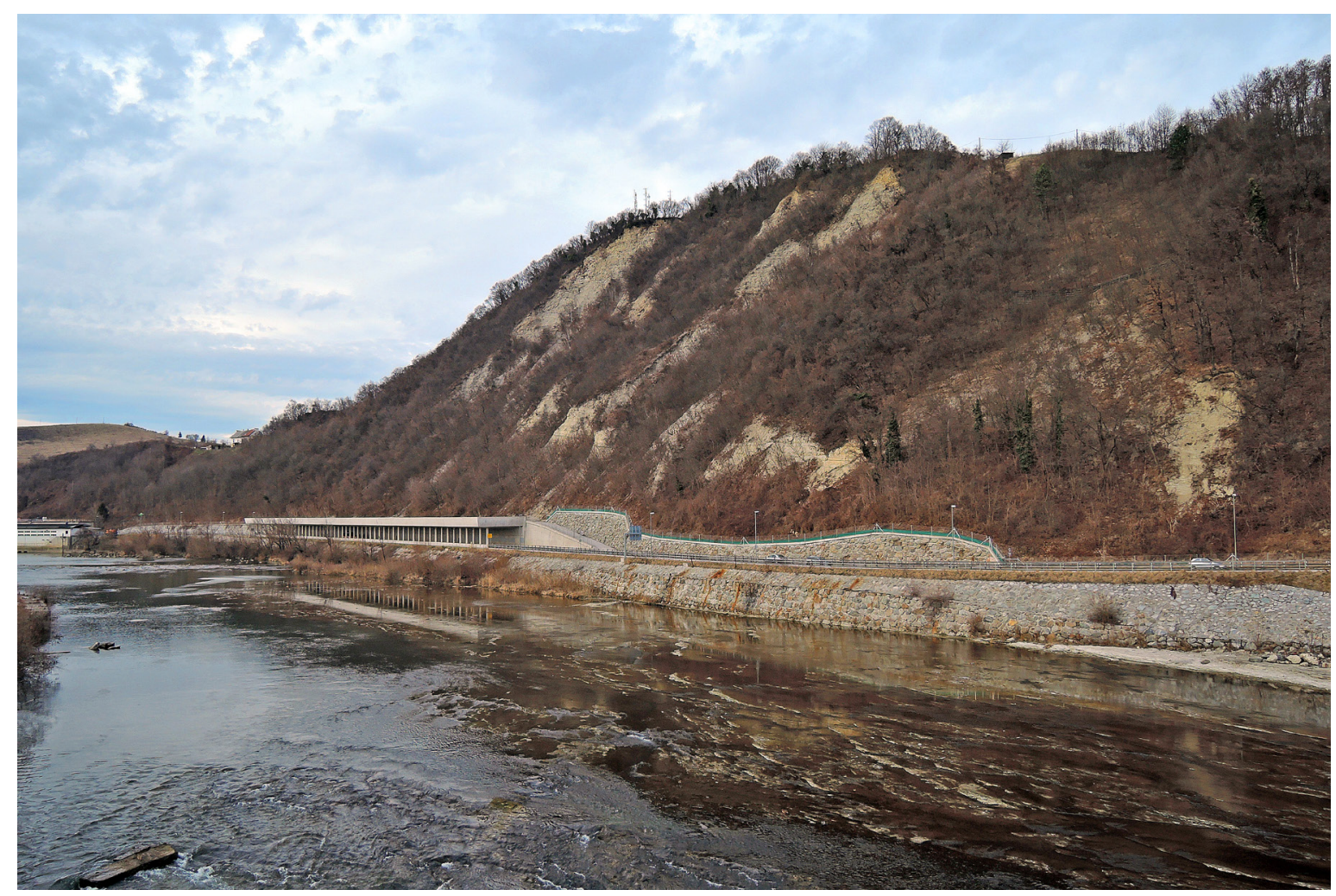

Figure 2 Strata of lower Miocene marls and siltstones forming cliffs above the Drava river near the town of Maribor (Slovenia). 
lateral spines; dorsolateral margins of rostrum continued back onto carapace as more or less parallel ridges bearing 3 to 5 pairs of prominent spines; antennal spine greatly expanded, lamellate; usually 7 longitudinal ridges on carapace posterior to postcervical groove. Scaphocerite broad, often circular in shape. First pair of pereiopods almost symmetrical (after Jenkins, 1972).

Remarks: Genera that are morphologically similar to Metanephrops are: Nephrops, to which most of the extant Metanephrops species have been previously assigned, Paraclythia and Hoploparia. Metanephrops can be distinguished easily from Hoploparia by the possession of a supraorbital carina with three to five spines, three pairs of thoracic carinae and isochelous first pereiopods. From Nephrops it differs by the presence of the branchial carina, which is absent in Nephrops and prominent supraorbital and antennal carina, which are distinctly shorter in Nephrops. Unlike Metanephrops, Paraclythia has highly sculpted abdominal terga and pleura, and the submedian carinae on the telson of Paraclythia converge posteriorly, while those of Metanephrops diverge. Paraclythia also differs from Metanephrops by its distinctly heterochelous chelipeds, which are more like those of homarid lobsters.

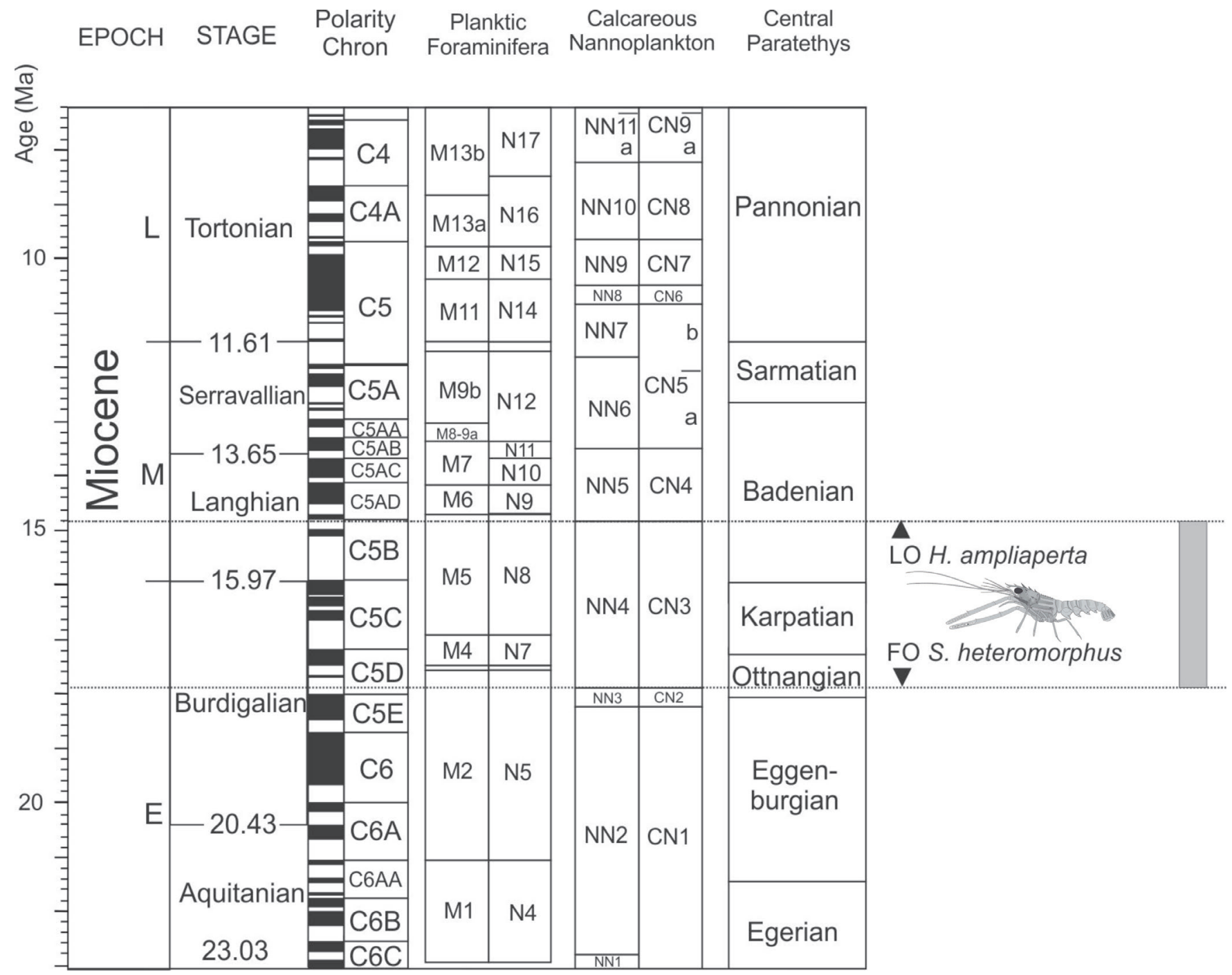

Figure 3 Chronostratigraphic chart of the Miocene, showing the Mediterranean and Central Paratethyan stages. The age of locality based on nannoplankton analysis is marked in grey. Modified after Kováč et al., 2018. 


\section{Metanephrops serendipitus sp. nov.}

Figures 4, 5 and 6A-H

Etymology: The specific name refers to the serendipitous find of the holotype carapace, which was found five years later than the associated chelipeds from the same location.

Diagnosis: Medium-sized Metanephrops with a robust body and long, slender and almost equal chelae. Spinulose carapace with three teeth on supraorbital carinae and three pairs of robust, wide and spinulose carinae of the branchiostegite. The intermediate carina splits and forms two separate ridges. Carapace spines including the antennal spine ornamented with rounded pits with a raised posterior rim, appearing spinulose themselves. Abdominal tergites marked by a transverse groove; especially in tergites 2 and 3, which also bear a concave "eyebrow" furrow and a bilobate tergite-pleuron boundary; tergite cuticle coarsely pitted. Tailfan spinulose; telson sub-rectangular, with spines at the postero-lateral angles and a pair of submedian spines in the anterior part. The first pair of pereiopods long and slender; over twice the length of carapace; chelae fingers as long as the palm, occlusal margin of the propodus adorned with a row of small, sharp teeth; every fifth tooth larger than the rest and a single large triangular tooth at the proximal quarter length from the hinge.
Types: The holotype is RGA/SMNH 2295 (cephalothorax and abdomen) (Figures 5 and 6A-C), together with RGA/SMNH 2296 (tail fan) (Figure 6D) and RGA/SMNH 1590/1591 (chelipeds) (Figures 5 and $6 \mathrm{~F}-\mathrm{H}$ ).

Measurements of holotype: (See table 1).

Type locality: Meljski hrib, Maribor (Slovenia).

Stratigraphical age: Early Miocene (Ottnangian-Karpatian; nannofossil biozone NN4 (Martini, 1971)).

Distribution: To date, known only from the type locality.

Description: Medium-sized lobster with a robust body and long, slender and almost equal chelae, showing all the characteristic features of the genus as described by Jenkins (1972).

The rostrum is slender and approximately half of the carapace length, about as long as antennal peduncle. Partially preserved in dorsal view and damaged (Figure 6E). The dorsal surface of the rostrum is concave with a median dorsal carina. A pair of lateral rostral teeth at mid-length (broken) and an anteriorly positioned robust subrostral spine.

A pair of well-developed supraorbital (postrostral) dorsal carinae continue posteriorly from the rostrum to the cervical groove. Each carina is armed with three even-spaced strong teeth. The carinae converge posteriorly in straight lines

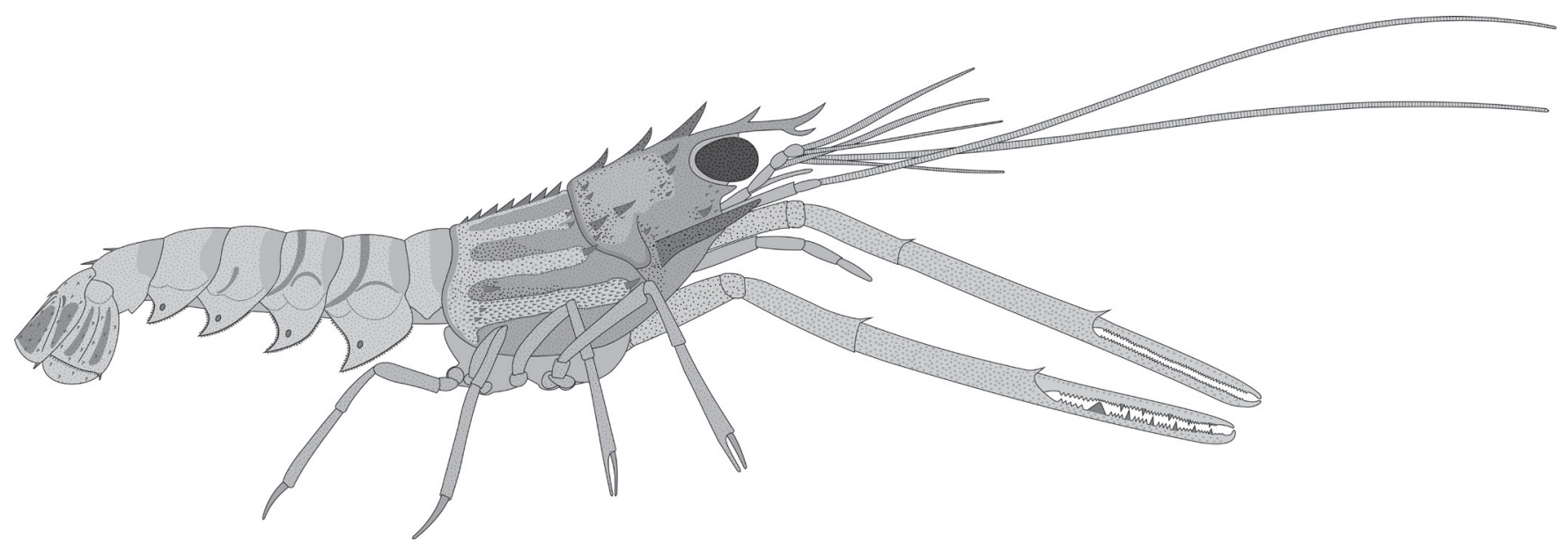


towards the postcervical groove. The teeth are pitted and decrease in size posteriorly from the largest anterior tooth, which is the only one with a slightly concave dorsal border; the others are straight. The region between the carinae is flat, depressed and finely pitted. Posterior to the postcervical groove, the ridges continue in a pair of thoracic median carinae, which are adorned by seven smaller spines of equal size, except for the posterior two, which are smaller. The area between the teeth of thoracic median carinae is ornamented with anteriorly facing scales.

The postcervical groove is strong and deeply impressed, running across the carapace at two thirds length. The dorsal portion of the groove is vertical and strongly concave anteriorly; lateral portion obliquely crosses the branchiostegite and becomes shallower anteriorly and ventrally. The groove is broad, smooth, with a shallow anterior margin and a more defined posterior margin, especially in the dorsal portion, where a parallel ridge is formed posteriorly. By contrast, hepatic and cervical grooves are faintly impressed; cervi- cal groove curves behind the antennal spine and extends half of the carapace dorsally.

Carapace is generally covered with spines and spinules (Figure 6C); antennal spine is the prominent and starts as a raised ridge anterior of the faint cervical groove; anteriorly strengthening and flattening to broad, flat and laminar spine curved slightly upwards anteriorly; extending beyond the orbit line. Additional pair of prominent spines is positioned higher and posterior to the antennal spine; first one at mid carapace, just anterior to the postcervical groove there is a strong cervical spine followed anteriorly by an almost equally strong gastrolateral spine. A small hepatic spine is present ventrally in a smooth depression close to the postcervical groove. A few further very small spines are situated in the region where the supraorbital carinae meet the postcervical groove. Several spines are situated on the upper antero-lateral part of the carapace. A small antero-laterally directed spine lies behind the posterior orbital margin. A smaller and less acute spine lies immediately below it. All prominent spines are ornamented by roun-

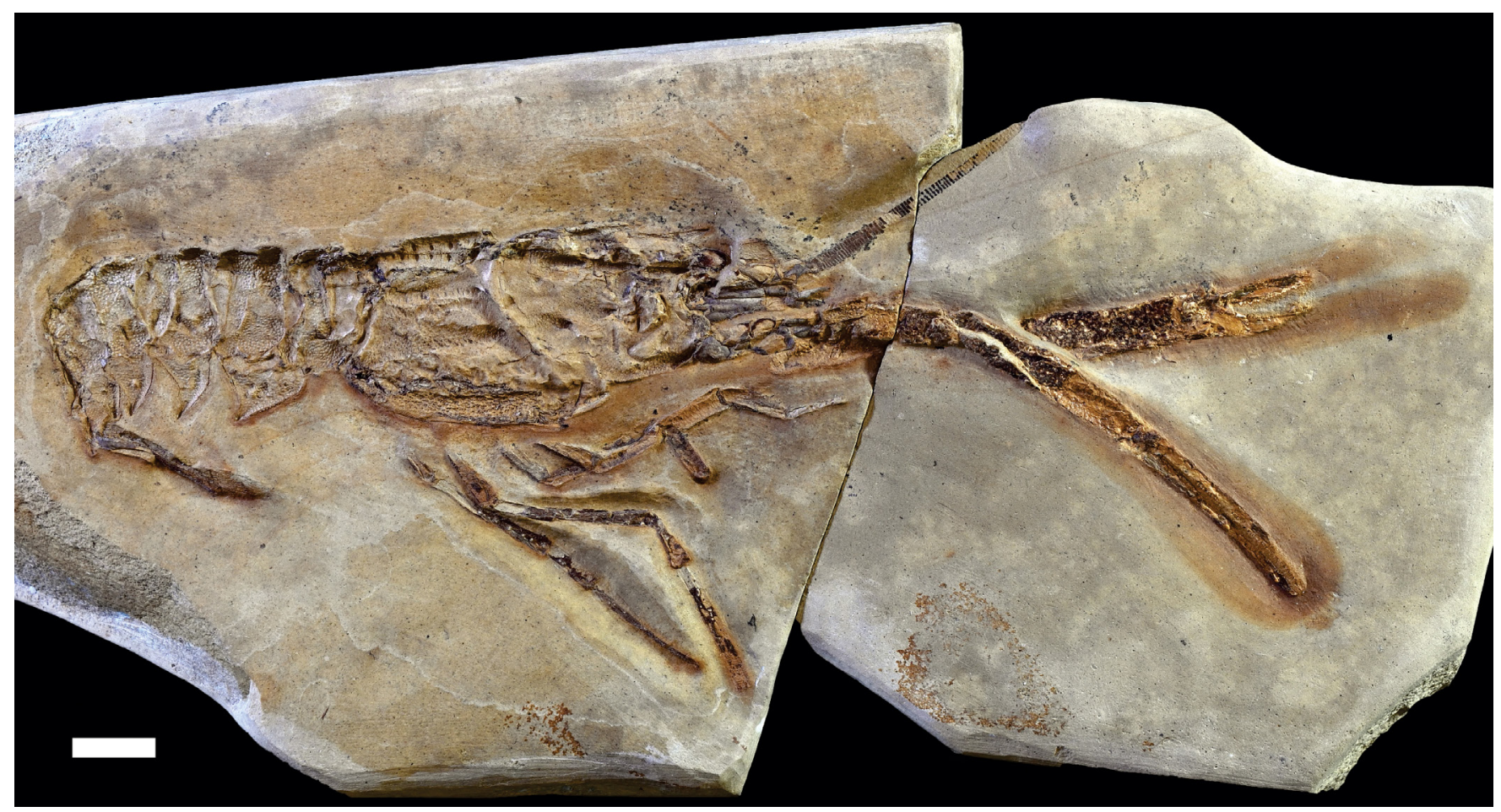

Figure 5 Metanephrops serendipitus sp. nov., holotype specimen RGA/SMNH 2295 (carapace) and RGA/SMNH 1591 (chelipeds). Scale bar equals $10 \mathrm{~mm}$. 
Table 1. Key measurements of Metanephrops serendipitus sp. nov. (in millimetres).

\begin{tabular}{|l|c|c|}
\hline & Length $(\mathrm{mm})$ & Width $(\mathrm{mm})$ \\
\hline Rostrum & 17.2 & 3.3 \\
Carapace & 35.2 & 20.5 \\
Tergit I & 6.8 & 12.2 \\
Tergit II & 8.6 & 19.8 \\
Tergit III & 8.0 & 19.2 \\
Tergit IV & 7.5 & 17.6 \\
Tergit V & 6.8 & 15.4 \\
Tergit VI & 7.4 & 5.9 \\
Telson & 13.5 & 10.9 \\
Total length & 111.0 & $\mathrm{X}$ \\
\hline
\end{tabular}

ded spinulose pits with raised posterior rim likely representing setal pits.

The branchiostegite region is decorated by three pairs of carinae, which are progressively wider and stronger from dorsal to ventral. The narrow uppermost intermediate carina runs parallel to the dorsal margin;the anterior half is split in two separate ridges, each ending with a small obtuse spine; whole carina is covered with small blunt spinules. The second carina is slightly downturned and posteriorly joined with the intermediate carina by a raised area covered with small blunt spinules which get coarser ventrally. Branchial carina is raised; wider posteriorly and bearing coarser pointy spinules; anteriorly it ends with a small pointy spine. The broad, lowermost lateral carina is oblique, pointed downwards anteriorly and is densely covered by squamous, anteriorly directed spinules; ending with a pointy upturned spine. The area between the branchial and lateral carinae bears a couple of smaller spines located posteriorly in the area where both carinae meet.

Topography of the abdominal tergites is partly obscured by compaction and deformation (Figure $6 \mathrm{~B})$. Tergite cuticle is very unusual among clawed lobsters in being very coarsely pitted - almost reticulate so at just above the pleura. We considered but rejected the possibility that this pitting was a taphonomic artefact.

Abdomen with tergite 1 rectangular, narrowest dorsally, widening slightly, gradually towards the pleuron. Tergites 2, 3, 4 rectangular, of similar shape and proportions. Tergite-pleuron boundary bilobate on segments 2, 3; less obviously on segments 4, 5. Anterior lobe larger than posterior one. Tergites 2, 3 marked by an arcuate transverse groove that extends anterodorsally from the posterolateral corner; groove appears to terminate below dorsomedian. On tergite 4, this groove is apparent only laterally. Tergites 2, 3 marked by a concave-down, 'eyebrow' furrow (see Tshudy et al., 2007). Cuticle here is much smoother, less pitted. Tergites have articular surfaces mostly smooth, with sparse minute pits. Articular and non-articular surfaces separated by a transverse groove. Dorsal margin of the sixth abdominal segment is armed with two posteriorly directed small spines.

Abdominal pleuron 1 small, obtusely triangular and directed ventrally. On somites 2-5, the boundary between the tergites and the pleura is marked by a sharp drop-off from the inflated tergite margin. Pleuron 2 subquadrate, with almost straight to slightly convex front margin and recurved hind margin forming a posteriorly shaped spine. Pleuron 2 is, by far, broadest. Pleura 3, 4, 5 petal-like, of similar width (5 narrower) and terminating in a posteriorly-directed spine. The lower posterior portion of the second to fifth pleura, just behind the tip, contains a distinct subcircular pit. The ventral margins of pleurae are serrated. Surface of pleura 2-5 with a submedian ridge; finely pitted and ornamented with small, elongate granulations.

The telson is subrectangular, with gently convex lateral and posterior margins with well-developed spines at the postero-lateral angles (Figure 6D). There are longitudinal lateral depressions and a median triangular depression posterior to the pair of submedian spines situated in the anterior part; otherwise the telson is finely spinulose. The posterior margin of the telson is fringed with long setae. Uropods are incompletely preserved. Endopod spinulose, with longitudinal median ridge; distal margin smoothly rounded, setose. Borders of exopod seem to be gently convex, with an acute spine at the lateral margin. Exopod with a longitudinal median ridge; diaeresis border of the lobed basal segment bears small spinules. 

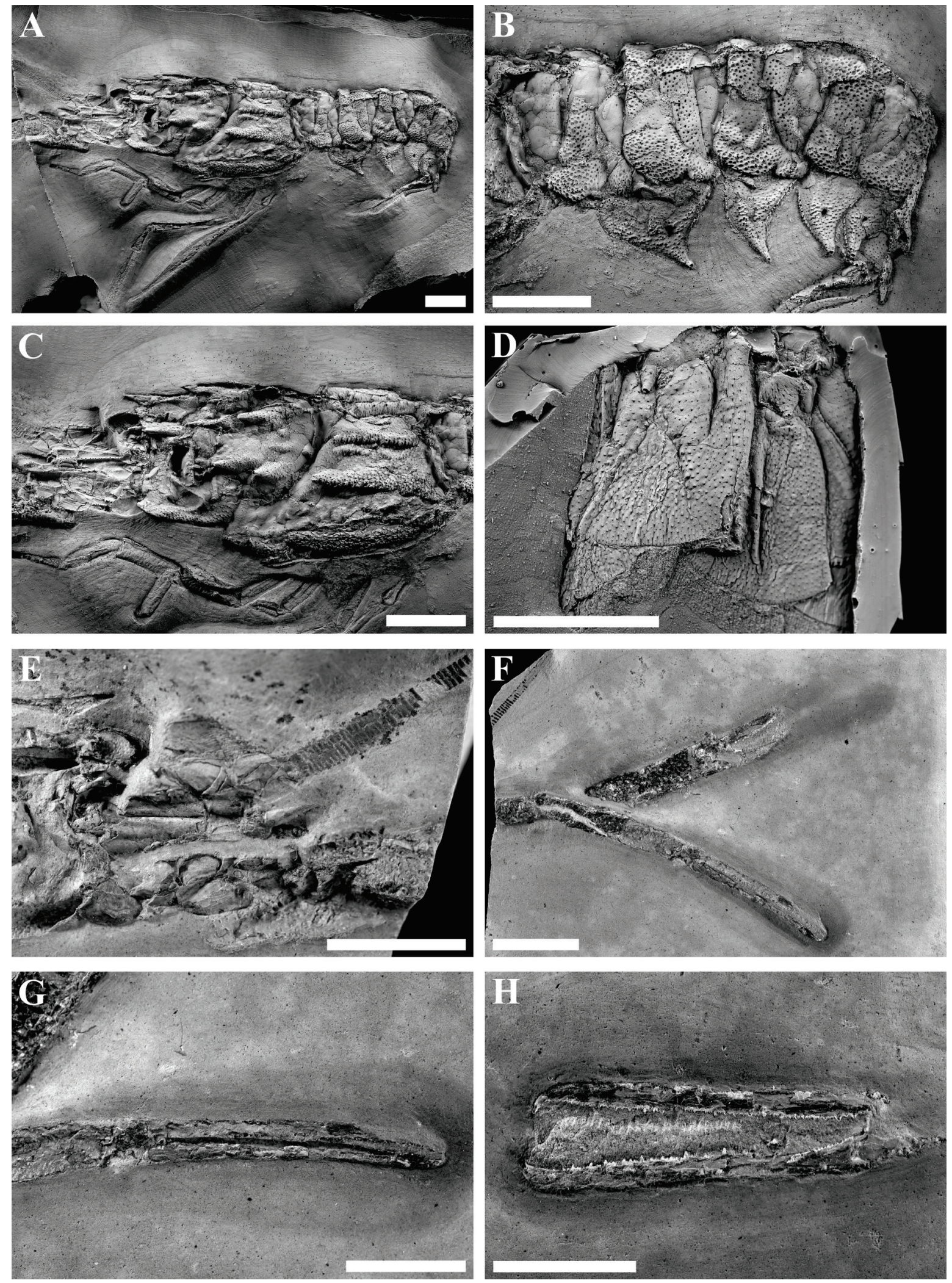

Figure 6 Metanephrops serendipitus sp. nov. A). RGA/SMNH 2295, carapace cast, whitened with ammonium chloride, B). RGA/SMNH 2295, detail of abdominal segments, cast, whitened, C. RGA/SMNH 2295, detail of carapace, cast, whitened, D). RGA/SMNH 2296, tailfan with telson detail, cast, whitened, E). RGA/SMNH 2296, rostrum with antenna and eye, $F$ ). RGA/SMNH 1591, chelipeds, G). RGA/SMNH 1591, detail of left chela, $H$ ). RGA/SMNH 1590, detail of right chela. All scale bars are $10 \mathrm{~mm}$. 
First, fourth and fifth pair of pereiopods are preserved, but lack their proximal segments; thus, ischium and merus are not known. The first pair of pereiopods is well developed, long and slender; well over twice the length of carapace (Figure 4); slightly asymmetrical, the left chela being slightly longer and slenderer than the right (Figure 6F). The carpus is elongated and granulated, a strong spine is present proximally at the dorsal edge of the articulation with the propodus. Propodus is by far the longest segment, being about four and a half times of the length of the carpus. The surface is coarsely granulated and does not exhibit any ridges, but this could be due to the flattened preservation; a distinct spine lies at the dorsal edge of the articulation with the dactylus. Chela appears dorso-ventrally compressed; fingers are as long as the palm, gently curved, decorated by a single row of coarse granules and ending in a curved pincer-like, hooked tips. The occlusal margin of the fixed finger of the right chela is adorned with a row of small, sharp teeth; about every fifth tooth is larger than the rest; the teeth get gradually smaller distally (Figure $6 \mathrm{H}$ ). The cutting edge is interrupted at about one fourth of its length from the hinge by a single large triangular tooth. Proximal to this interruption the teeth are very small. The cutting edge of the dactylus is similar, with the exception that there is no prominent triangular tooth, and the row of smaller teeth opposite from it is further reduced in size. The bigger teeth on the dactylus are positioned to be interspaced between the bigger teeth of fixed finger and never achieve their size. The distalmost parts before the curved tips are smooth and not armed by teeth. The occlusal margin of the left chela is simpler, adorned with regularly interspaced small sharp teeth; there are several bigger teeth on both fixed finger as well as on the dactylus, but they do not exhibit the pattern of regularity or size of the teeth in the right chela (Figure 6G).

The fourth and fifth pereiopods are long and slender, irregularly covered with coarser granules, less dense as on the first pereiopods. The eye and antennae are partially preserved; corneae are large and ovate. Antennae are robust, long and straight and appear more rigid then the antennulae.

\subsection{DISGUSSION}

Extant species of Metanephrops have traditionally been divided into four morphologic groups based on the form and ornamentation of the cephalothorax, abdominal terga, and the chelipeds (see Jenkins, 1972; Chan, 1997). Three of these have been supported as monophyletic in a recent cladistic analysis (Tshudy et al., 2007), but molecular analysis only proved two of them as monophyletic (Chan et al., 2009).

The binghami group is characterized by a generally smooth carapace except for a heavily spinulose cervical groove, unsculptured abdominal terga, uropods spineless dorsally, and by chelipeds that exhibit six spiny, longitudinal carinae and a flat outer margin. The japonicus group is characterized by a generally smooth carapace, distinctly sculptured abdominal terga, uropods spineless dorsally, and spiny, carinate chelipeds with an outer border somewhat flat but with a longitudinal, medial depression. The thomsoni group is characterized by a smooth carapace, abdominal terga that are either completely unsculptured or traversed by a transverse furrow interrupted medially, uropods spineless dorsally and also by weakly carinate, nearly smooth to finely granulate chelipeds with outer margin always angular. Finally, the arafurensis group is characterized by a uniformly spiny carapace, abdominal terga that are deeply marked by at least one or two transverse furrows, by uropods spinulose on the dorsal surface, and by weakly carinate, finely granulose to spiny chelipeds with the outer margin always being angular (Table 2).

From currently described fossil species, Metanephrops motunauensis Jenkins, 1972 falls in the arafurensis group, whereas according to Tshudy et al. (2007), neither of the two Cretaceous fossil species, M. jenkinsi Feldmann, 1989 and M. rossensis Feldmann et al., 1993, fits easily into any of the four groups. Additionally, the abovementioned specimen of Metanephrops sp. from the upper Eocene of Italy described on the basis of partially preserved chelipeds (Garassino et al., 2003) cannot be assigned to any of the traditional groups. However, the arrangement of crushing teeth on the inner 
Table 2. Overview of key morphological features for Metanephrops groups. Showing the attribution of fossil species of Metanephrops. ( $\mathrm{S}=$ Metanephrops serendipitus sp. nov.; $\mathrm{M}=$ M. motunauensis Jenkins, 1972; $\mathrm{R}=\mathrm{M}$. rossensis Feldmann et al., 1993; $\mathrm{J}=\mathbf{M}$. jenkinsi Feldmann, 1989).

\begin{tabular}{|c|c|c|c|c|}
\hline Feature / Group & binghami & japonicus & arafurensis & thomsoni \\
\hline Carapace texture & smooth $(\mathrm{J}, \mathrm{R})$ & $\operatorname{smooth}(J, R)$ & spiny $(\mathrm{M}, \mathrm{S})$ & smooth $(\mathrm{J}, \mathrm{R})$ \\
\hline Cervical spinules & yes $(R)$ & no $(\mathrm{J}, \mathrm{S})$ & yes $(R, M)$ & varies \\
\hline Poslcervical spines & yes $(J, R)$ & no $(\mathrm{S})$ & varies $(\mathrm{M})$ & no \\
\hline Postantennal spines & yes $(J, R)$ & no $(\mathrm{S})$ & no $(\mathrm{M}, \mathrm{S})$ & no $(\mathrm{S})$ \\
\hline Supracervical spine & yes $(J)$ & no $(\mathrm{R}, \mathrm{S})$ & no $(\mathrm{R}, \mathrm{M}, \mathrm{S})$ & no $(\mathrm{R}, \mathrm{S})$ \\
\hline Terga sculptured & no $(J, R)$ & highly & highly (M) & none-lillle (S) \\
\hline Scales facade & no & yes (6 of 7) & no $(\mathrm{M}, \mathrm{S})$ & no $(\mathrm{S})$ \\
\hline Cheliped outer mgn & flat/spiny $(\mathrm{J}, ? \mathrm{~S})$ & flat/spiny $(\mathrm{J}, ? \mathrm{~S})$ & angular / less spiny $(\mathrm{R}, \mathrm{M})$ & angular/ less spiny $(\mathrm{R})$ \\
\hline Uropods spiny & no & no & spiny $(\mathrm{M}, \mathrm{S})$ & no \\
\hline
\end{tabular}

margin of the propodus of the large cheliped in the Italian fossil appears peculiar as the crushing teeth are limited only to the posterior part of the finger in Metanephrops. Thus, we have some reservations concerning the assignment of the Italian specimen to Metanephrops.

Metanephrops serendipitus sp. nov. has a spiny carapace and tailfan, and seems to be most closely aligned with the species from the arafurensis group, which includes Metanephrops arafurensis (De Man, 1905), Metanephrops neptunus (Bruce, 1965), and Metanephrops australiensis (Bruce, 1966), although it also shares some of the similarities with the representatives of the japonicus group (Table 2).

The major differences with the representatives of the arafurensis group are that the carapace has also areas that are less spinous (such as the lack of cervical spinules) and the unclear presence of carinae on the chelipeds, which could be attributed to the preservation of the fossil material. Metanephrops serendipitus sp. nov. differs from M. neptunus in possessing a single transverse groove on the non-articular surface of the abdominal terga; much stronger and spinous carinae on the branchiostegite, the areas between are variably ornamented from gentle pitted to squamous. Chelipeds of the new species are significantly longer, straighter, slenderer and granulose, not spiny as in $M$. neptunus, to which the new species resembles in possessing three pairs of spines on the postrostral carinae. Moreover, the chela has the finger distinctly longer than the palm and the region between the postrostral carinae being heavily spinulose in $M$. neptunus. The fossil species is similar to $M$. australiensis in possessing a single transverse groove on the abdominal terga, overall shape and decoration of carapace including the positions of spines and dorsal carinae, and long and slender, not spinous, chelipeds. However, Metanephrops serendipitus sp. nov. differs from $M$. australiensis in its abdominal tergites 2 and 3 marked by a distinct eyebrow furrow; possessing only three pairs of spines on postrostral carinae; the cheliped fingers are longer and similar as the palms decorated with coarse granules. Metanephrops serendipitus sp. nov. has abdominal terga with ornamentation very similar to that of $M$. arafurensis, from which it differs by possessing only three pairs of spines on the postrostral carinae, by having carapace and chelipeds not uniformly spiny, but rather variably ornamented by pits, granules and occasional spines, and by having carinae of the branchiostegite wider, with an intermediate carina branching and with two anteriorly oriented spines. As far as a comparison between the two arafurensis-like fossil species is possible, the Miocene Metanephrops serendipitus sp. nov. differs from $M$. motunauensis from the Pliocene of New Zealand by possessing only three pairs (not four) of spines on the postrostral carinae, by having only two pairs (not three) of dorsal spines on the sixth abdominal tergite, by lacking spines on the lateral part of sixth abdominal tergite, and by having a strongly granulated to squamous ornamentation of the carapace. 

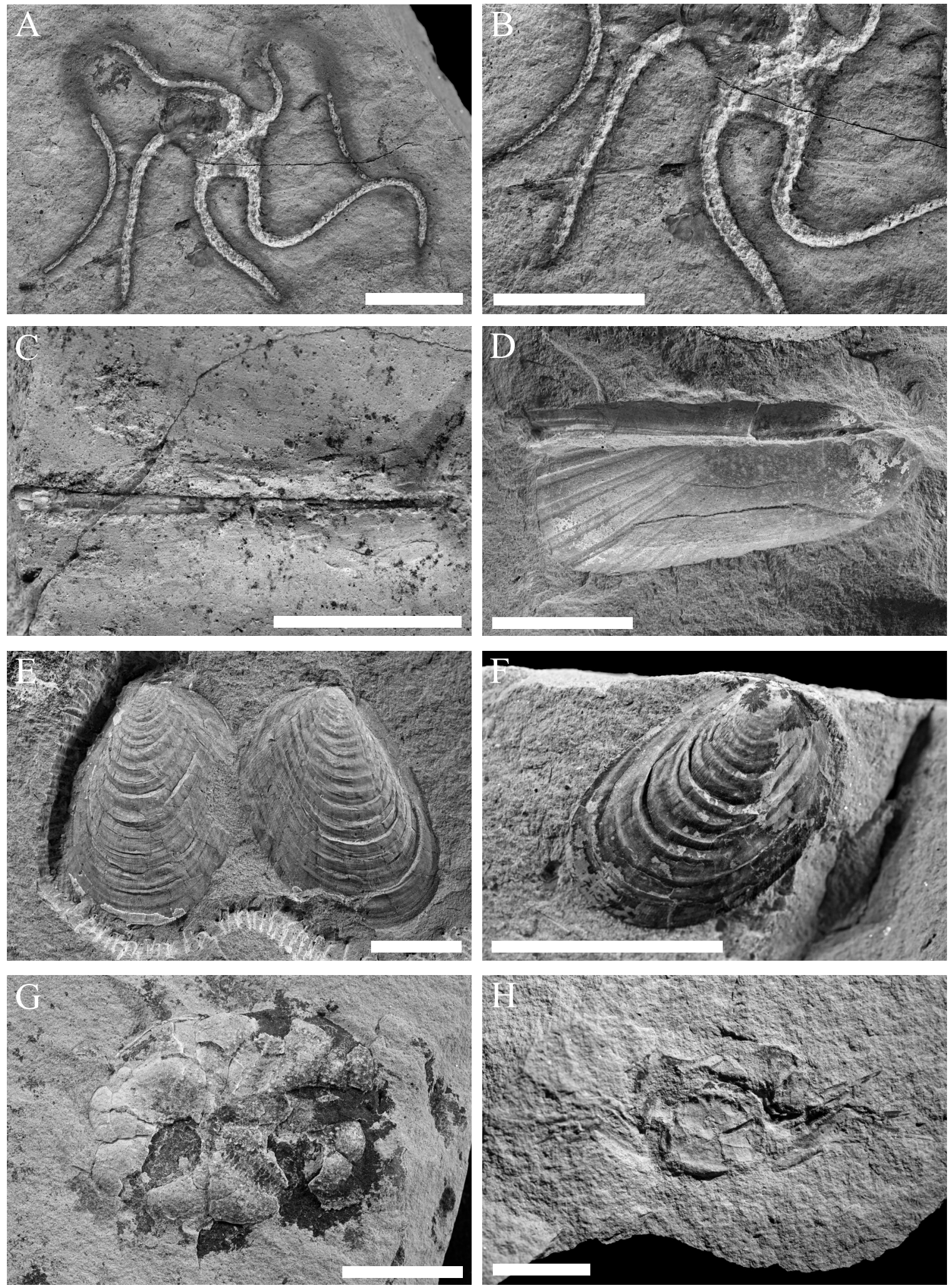

Figure 7 Associated fauna. A). RGA/SMNH 1588, undetermined ophiuroid with fish scale and scaphopod Gadilina taurogracilis Sacco, 1897, B).RGA/SMNH 1588, detail of Gadilina taurogracilis Sacco, 1897, C).RGA/SMNH 4895, Gadilina taurogracilis Sacco, 1897, D).RGA/ SMNH 2746, Solemya doederleini Mayer, 1861, E).RGA/SMNH 2769, Limaria Iabani (Meznerics, 1936), F).RGA/SMNH 4896, Limaria Iabani (Meznerics, 1936), G).RGA/SMNH 2750, undetermined irregular echinoid, H).RGA/SMNH 1676, Styrioplax exiguus (Glaessner, 1928). All scale bars are $10 \mathrm{~mm}$. 
Also, this new species shows some resemblance to the members of japonicus group in the positions and shape of the carinae of the branchiostegite, the ornamentation of the abdominal tergites, and the shape of chelipeds. In overall appearance, it most closely resembles $M$. australiensis, but it shares three spines on the postrostral carina with $M$. neptunus and the ornamentation of the terga with M. arafurensis.

\subsection{GALGAREOUS NANNOPLANKTON}

The investigated sample contains numerous well-preserved calcareous nannofossils presented by 34 autochthones and 8 allochthones taxa (Figure 8,1-44). The assemblage is highly dominated by small-sized Reticulofenestra minuta Roth 1970, Reticulofenestra minutula (Gartner 1967) Haq and Berggren 1978 and Reticulofenestra haqii Backman 1978 with $60.5 \%$, followed by Coccolithus pelagicus (Wallich 1877) Schiller 1930 yielding 25.0\% of the entire amount of nannofossils. Helicoliths are presented by Helicosphaera ampliaperta Bramlette and Wilcoxon 1967, H. carteri (Wallich 1877) Kamptner 1954, H. euphratis Haq 1966, H. gertae Bukry 1981, H. mediterranea Müller 1981, H. scissura Miller 1981, H. theodoridisii de Kaenel and Boesiger in Boesiger et al. 2017, H. vedderi Bukry 1981, H. walbersdorfensis Müller 1974, and Helicosphaera sp.

Among sphenoliths, the stratigraphically important Sphenolithus heteromorphus Deflandre 1953, S. disbelemnos Fornaciari and Rio 1996, S. conicus Bukry 1971, S. milanetti Maiorano and Monechi 1998 and S. procerus Maiorano and Monechi 1997 were observed.

Discoasters are very rare and presented by medium-sized (10-15 $\mu \mathrm{m})$ Discoaster druggii Bramlette and Wilcoxon 1967 and Discoaster deflandrei Bramlette and Riedel 1954.

The sediment also contains rare pentaliths of Braarudosphaera bigelowii (Gran and Braarud 1935) Deflandre 1947. The following taxa occur in low abundance: Calcidiscus leptoporus (Murray and Blackman 1898) Loeblich and Tappan 1978, Coccolithus miopelagicus Bukry 1971, Coccolithus tenuiforatus (Clocchiatti and Jerkovic 1970) Wise 1983,
Cyclicargolithus floridanus (Roth and Hay in Hay et al. 1967) Bukry 1971, Pontosphaera discopora Schiller 1925, Pontosphaera multipora (Kamptner 1948 ex Deflandre in Deflandre and Fert 1954) Roth 1970, Reticulofenestra perplexa (Burns 1975) Wise 1983, Sphenolithus moriformis (Brönnimann and Stradner 1960) Bramlette and Wilcoxon 1967, and Umbilicosphaera jafari Muller 1974.

Reworked nannofossils are rare $(<5 \%)$ and represented by Eocene/Oligocene taxa Coccolithus formosus (Kamptner 1963) Wise 1973, Reticulofenestra bisecta (Hay, Mohler and Wade 1966) Roth 1970 and Reticulofenestra dictyoda (Deflandre in Deflandre and Fert 1954) Stradner in Stradner and Edwards 1968) and Maastrichtian species: Ceratolithoides arcuatus Prins and Sissingh in Sissingh 1977, Microrhabdulus decoratus Deflandre 1959 and Watznaueria barnesiae (Black in Black and Barnes 1959) Perch-Nielsen 1968).

\section{5. palaeobiogeography and depositional environment}

Previously, the genus Metanephrops was thought to have originated in the Indo-West Pacific and arrived in the Atlantic through the Tethys Sea before or during the Lower Miocene (Jenkins, 1972; Chan, 1997). Latest phylogenetic analyses, however, suggested that these lobsters have a Gondwana Weddell origin with dispersal routes primarily along continental shelves rather than across open seas (Chan et al., 2009). Amongst the extant members of the genus, the binghami group, $M$. challengeri and $M$. neptunus are thought to be more primitive (Chan et al., 2009). According to the Gondwana Weddell origin hypothesis, Metanephrops lobsters reached the Atlantic at their rather early, instead of late, stage of evolution, and only in the western side. The entering to the Mediterranean was by the dispersal from the northern Indian Ocean, before the connection between the Mediterranean and the Indian Ocean was closed (around mid-Miocene, Rögl, 1999). The discovery of a rather modern Metanephrops 


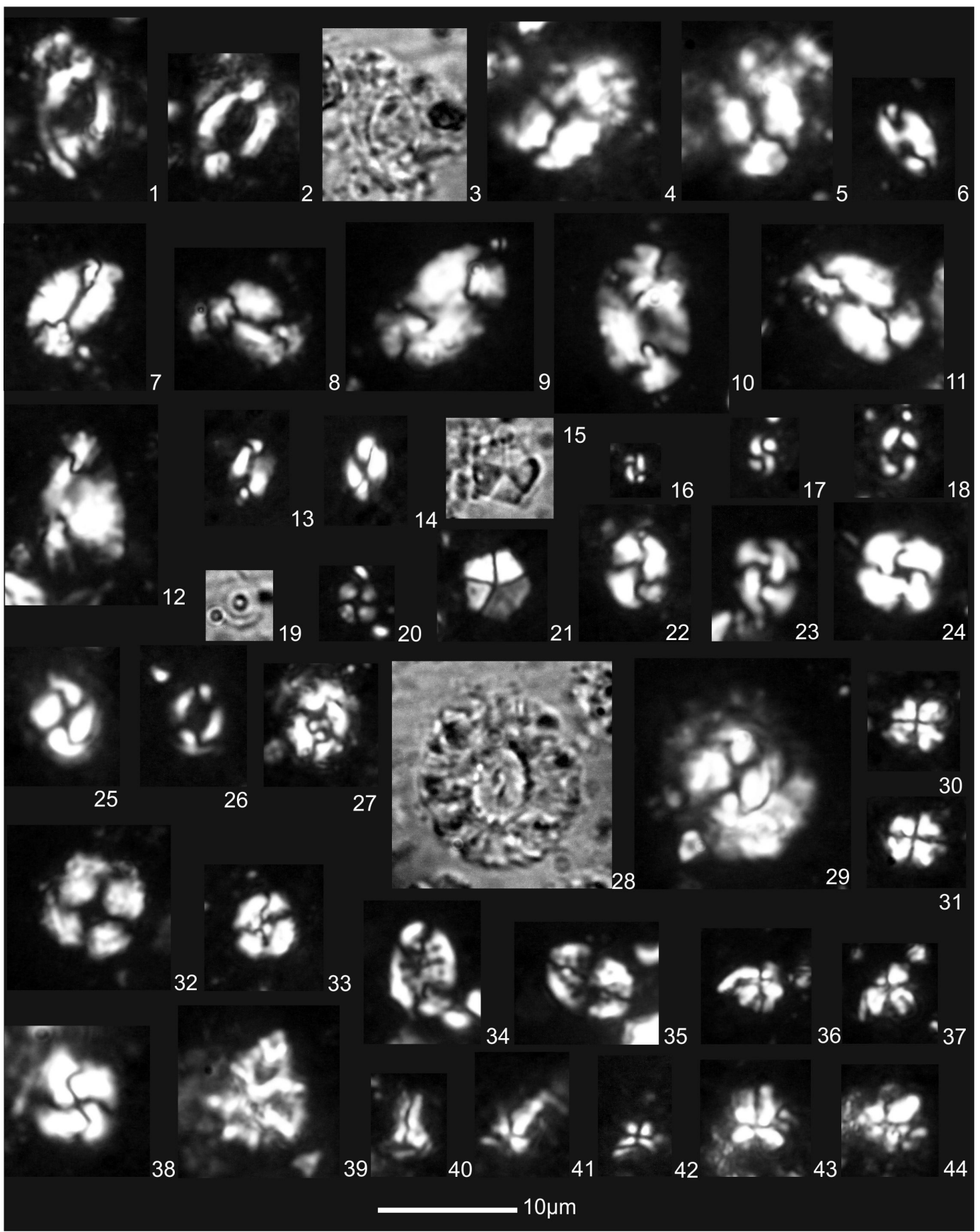

Figure 8 Calcareous nannofossils. ( 1 - 5). Helicosphaera ampliaperta Bramlette and Wilcoxon 1967, (6). Helicosphaera vedderi Bukry 1981, (7 - 8). Helicosphaera scissura Miller 1981, (9 - 11). Helicosphaera scissura Miller 1981, (12). Helicosphaera gertae Bukry 1981, (13, 14). Helicosphaera walbersdorfensis Müller 1974, (15, 21$)$. Braarudosphaera bigelowii (Gran and Braarud 1935) Deflandre 1947, (16, 17). Reticulofenestra minuta Roth 1970, (18). Reticulofenestra haqii Backman 1978, (19, 20). Umbilicosphaera jafari Müller 1974, (22, 23). Reticulofenestra perplexa (Burns 1975) Wise 1983, (24). Cyclicargolithus floridanus (Roth and Hay in Hay et al. 1967) Bukry 1971, (25, 26). Coccolithus pelagicus (Wallich 1877) Schiller 1930, (27). Coccolithus tenuiforatus (Clocchiatti and Jerkovic 1970) Wise 1983, (28, 29). Coccolithus miopelagicus Bukry 1971, (30, 31). Sphenolithus moriformis (Brönnimann and Stradner 1960) Bramlette and Wilcoxon 1967, (32). Coccolithus formosus (Kamptner 1963) Wise 1973, (33). Watznaueria barnesiae (Black in Black and Barnes 1959) Perch-Nielsen 1968, (34, 35). Pontosphaera multipora (Kamptner, 1948 ex Deflandre in Deflandre and Fert 1954) Roth 1970, (36, 37). Sphenolithus milanetti Maiorano and Monechi 1998, (38). Reticulofenestra bisecta (Hay, Mohler and Wade 1966) Roth 1970, (39). Lithostromation perdurum Deflandre 1942, (40). Zygrhablithus bijugatus (Deflandre in Deflandre and Fert 1954) Deflandre 1959, (41, 42). Sphenolithus heteromorphus Deflandre 1953, (43, 44). Sphenolithus procerus Maiorano and Monechi 1997. Scale bar is 10 um. 
fossil in the Central Paratethys generally fits the Gondwana Weddell origin hypothesis. Moreover, the present fossil $M$. serendipitus sp. nov., is close to the more derived $M$. australiensis/arafurensis and the japonicus group as indicated in Chan et al. (2009). The japonicus group occurs in the entire Indian Ocean while $M$. australiensis has a range to the eastern Indian Ocean. The occurrence of older Metanephrops fossils (earlier than Oligocene) in the Mediterranean would falsify the southern higher latitude origin hypothesis but support the IndoWest Pacific origin hypothesis.

Most Recent Metanephrops species inhabit the deeper waters of the outer continental shelf and continental slope. Different species have been collected from depths between 50 and 1000 meters, but most commonly deeper than $150 \mathrm{~m}$ (Tshudy, 2003; Chan et al., 2009). The two Late Cretaceous (Campanian) Metanephrops species are known from shallower, inner shelf sediments, and a migration from shelf depths to deeper depths has been proposed and documented for several nephropid lobs- ter taxa (Beurlen, 1939; Mertin, 1941; Glaessner, 1969; Feldmann and Tshudy, 1989; Tshudy and Sorhannus, 2000; Tshudy, 2003).

The investigated calcareous nannofossil assemblage (Figure 8,1-44) with high percentage of small reticulofenestrids (Reticulofenestra minuta, $R$. minutula and $R$. haqi) accompanied by $C$. pelagicus and helicoliths points to the nearshore, a nutrient rich (eutrophic) marine environment (Okada and McIntyre, 1979; Haq, 1980; Winter et al., 1994; Ćorić and Rögl, 2004). Rare occurrences of discoasterids (D. deflandrei, D. druggii), which are characteristic for oligotropic oceanic water (Aubry, 1992; Lohmann and Carlson, 1981; Young, 1998) confirm this interpretation of the palaeoenvironment. Deep sedimentation basins in close proximity to nearshore environments are typical of the Mura Depression of Central Paratethys due to the prevailing extension tectonics in lower/middle Miocene (Bartol, 2009).

The associated crustacean fauna includes rare specimens of callianassid chelipeds and the crab

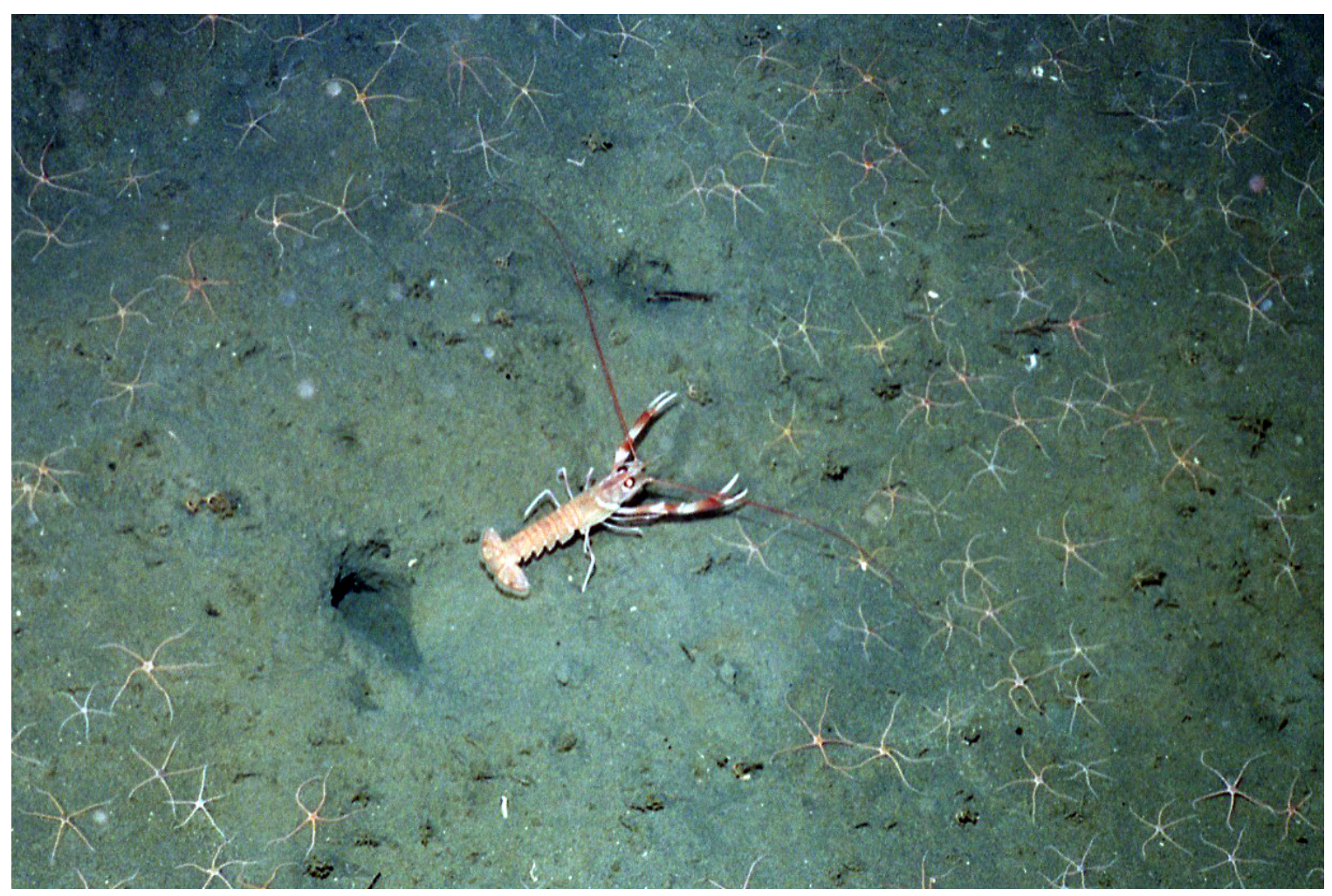


Styrioplax exiguus (Glaessner, 1928) (Figure 7H), which has so far been exclusively found in fine grained clastic rocks of deep-water facies (Hyžný and Schlögl 2011; Gašparič and Hyžný, 2015; Gašparič and Halasova, 2015). The specimen of Metanephrops serendipitus sp. nov. was recovered from strata containing a mass accumulation of indeterminable brittle stars (Figure 7A-B), which corresponds to the Metanephrops sagamiensis habitat at $426 \mathrm{~m}$ depth (Figure 9) as recorded by the Japan Agency for Marine-Earth Science and Technology (JAMSTEC, 1999) in the Suruga Bay off the eastern coast of Japan.

From associated molluscs, we identified the bivalves Solemya doederleini Mayer, 1861 (Figure 7D), Limaria labani (Meznerics, 1936) (Figures 7E and 7F), Lentipecten denudatus (Reuss, 1867), and Macoma elliptica (Brocchi, 1814), which have been all previously described from the deep-water facies of Cerová-Lieskové in the Slovak Republic part of the Central Paratethys (Harzhauser et al., 2011). Ecologically significant is the presence of the scaphopod Gadilina taurogracilis Sacco, 1897 (Figures 7B to 7C). Similar to the Pliocene species Gadilina triquetra (Brocchi, 1814), it is considered to be bathyal and indicative for unstable deep marine environments with high sedimentation rates (Ceregato et al., 2007; Harzhauser et al., 2011).

The associated fauna of the sediments at Meljski hrib locality indicates an outer shelf to slope environment with water depth of at least 150 $\mathrm{m}$ but likely exceeding $250 \mathrm{~m}$.

\section{Acknowledgements}

We wish to thank Andreja Žibrat Gašparič for her thorough proofreading and the journal reviewers, Günter Schweigert and Hiroaki Karasawa, for constructive comments on an earlier version of the manuscript. This work was supported by grants from the Ministry of Science and Technology, Taiwan, R.O.C. and the Center of Excellence for the Oceans (National Taiwan Ocean University), which is supported by the Featured Areas Research
Center Program within the framework of the Higher Education Sprout Project by the Ministry of Education in Taiwan, R.O.C.

\section{References}

Aubry, M. P., 1992, Late Paleogene calcareous nannoplankton evolution: a tale of climatic deterioration, in Prothero, D. R., Berggren, W. A. (eds.), Eocene-Oligocene Climatic and Biotic Evolution: Pronceton University Press, 272-309. https://doi. org/10.1515/9781400862924.272

Bartol, M., 2009, Middle Miocene calcareous nannoplankton of NE Slovenia (western Central Paratethys): Ljubljana, ZRC Publishing, 136 p. https://doi. org/10.3986/9789612545598

Bartol, M., Mikuž, V., Gašparič, R., 2013, Nekaj primerov datiranja makrofosilov s kalcitnim nanoplanktonom: Geološki zbornik, 22, 11-12.

Bartol, M., Mikuž, V., Horvat, A., 2014, Palaeontological evidence of communication between the Central Paratethys and the Mediterranean in the late Badenianearly Serrravallian: Palaeogeography, Palaeoclimatology, Palaeoecology, 394, 144-157. https://doi.org/10.1016/j. palaeo.2013.12.009

Beurlen, K., 1939, Neue Dekapoden-Krebse aus dem ungarischen Tertiär: Palaeontologische Zeitschrift, 21, 135-160. https://doi. org/10.1007/bf03043252

Bramlette, M. N., Wilcoxon, J. A., 1967, Middle Tertiary calcareous nannoplankton of the Cipero section, Trinidad: Studies in Geology and Paleontology, 5, 93-131.

Bruce, A. J., 1965, On a new species of Nephrops (Decapoda, Reptantia) from the South China Sea: Crustaceana, 9(3), 274-284. https://doi. org/10.1163/156854065x00055

Bruce, A. J., 1966, Nephrops australiensis sp. nov., a new species of lobster from 
northern Australia (Decapoda Reptantia): Crustaceana, 10(3), 245-262. https://doi. org/10.1163/156854066x00162

Ceregato A., Raffi S., Scarponi D., 2007, The circalittoral/bathyal paleocommunities in the Middle Pliocene of Northern Italy: The case of the Korobkovia oblonga - Jupiteria concava paleocommunity type: Geobios, 40, 555-572. https://doi.org/10.1016/j. geobios.2006.08.004

Chan, T. Y., Ho, K. G., Li, C. P., Chu, K. H., 2009, Origin and diversification of the clawed lobster genus Metanephrops (Crustacea: Decapoda: Nephropidae): Molecular Phylogenetics and Evolution, 50(3), 411-422. https://doi.org/10.1016/j. ympev.2008.11.020

Chan, T. Y., 1997, Crustacea Decapoda: Palinuridae, Scyllaridae and Nephropidae collected in Indonesia by the KARUBAR Cruise, with an identification key for the species of Metanephrops, in Crosnier, A., Bouchetm P. (eds.), Resultats des Campagnes MUSORSTOM, 16: Mémoires du Muséum National d'Histoire Naturelle, 172, 409-431.

Ćorić, S., Rögl, F., 2004, Roggendorf-1 borehole, a key section for Lower Badenian transgressions and the stratigraphic position of the Grund Formation: Geologica Carpathica, 55(2), 165-178.

Dana, J. D., 1852, Conspectus of the Crustacea of the exploring expedition under Capt. Wilkes, U.S.N.: Proceedings of the Academy of Natural Sciences of Philadelphia, 6, 6-28.

Deflandre, G., 1953, Hétérogénéité intrinsèque et pluralité des éléments dans les coccolithes actuels et fossiles: Comptes Rendus de l'Académie des sciences, 237, 1785-1787.

De Man, J. G., 1905, Diagnoses of new species of macrurous decapod Crustacea from the "Siboga-Expedition": Tijdschrift der Nederlandsche Dierkundige Vereeniging, 9, 587-614.

Feldmann, R. M., 1989, Metanephrops jenkinsi n. sp. (Decapoda: Nephropidae) from the Cretaceous and Paleocene of Seymour
Island, Antarctica: Journal of Paleontology, 63, 64-69. https://doi.org/10.1017/ s0022336000040968

Feldmann, R. M., Tshudy, D. M., 1989, Evolutionary patterns in macrurous decapod crustaceans from Cretaceous to early Cenozoic rocks of the James Ross Island region, Antarctica, in Crame, J. A. (ed.), Origins and Evolution of the Antarctic Biota: Geological Society Special Publication, 47, 183-195. https://doi.org/10.1144/gsl. sp.1989.047.01.14

Feldmann, R. M., Tshudy, D. M., Thomson, M. R., 1993, Late Cretaceous and Paleocene Decapod Crustaceans from James Ross Basin, Antarctic Peninsula: Journal of Paleontology, 67(1), 1-41. https://doi.org/10.1017/ s0022336000062077

Fodor, L., Jelen, B., Marton, E., Rifelj, H., Kraljić, M., Kevrić, R., Marton, P., Koroknai, B., BaldiBeke, M., 2002, Miocene to Quaternary deformation, stratigraphy and paleogeography in northeastern Slovenia and Southwestern Hungary: Geologija, 45(1), 103-114. https://doi.org/10.5474/ geologija.2002.009

Garassino, A., De Angeli, A., De Polli, R., 2003, Report of Metanephrops Jenkins, 1972 (Crustacea, Decapoda, Nephropidae) from the upper Eocene of Grancona, Vicenza, Italy: Atti della Società Italiana di Scienze Naturali e del Museo Civico di Storia Naturale di Milano, 144(2), 383-392.

Gašparič, R., Halasova, E., 2015, Nove najdbe rakovice Styrioplax exiguus Glaessner, 1928 (Decapoda, Brachyura, Chasmocarcinidae) $\mathrm{v}$ miocenskih plasteh okolice Maribora (New reports of crab Styrioplax exiguus Glaessner, 1928 (Decapoda, Brachyura) from Miocene beds near Maribor): Geologija, 58 (2), 201-212. https://doi.org/10.5474/ geologija.2015.016

Gašparič, R., Hyžný, M., 2015, An early Miocene deep-water Decapod Crustacean Faunule from the slovenian part of the Styrian Basin and its palaeoenvironmental and 
palaeobiogeographical significance: Papers in Palaeontology, 1(2), 141-166. https://doi. org/10.1002/spp2.1006

Glaessner, M. F., 1928, Die Dekapodenfauna des österreichischen Jungtertiärs: Jahrbuch der Geologischen Bundesanstalt, 78, 161-219.

Glaessner, M. F., 1969, Decapoda, in Moore, R., C., (ed.), Treatise on Invertebrate Paleontology, Pt. R4: Geological Society of America and University of Kansas Press, 400-533.

Haq, B. U., 1980, Biogeographic history of Miocene calcareous nannoplankton and paleocaenography of the Atlantic Ocean: Micropaleontology, 26(4), 414-443. https:// doi.org/10.2307/1485353

Harzhauser, M., Mandic, O., Schlögl, J., 2011, A late Burdigalian bathyal mollusc fauna from the Vienna Basin (Slovakia): Geologica Carpathica, 62(3), 211-231. https://doi. org/10.2478/v10096-011-0018-7

Hu, C. H., 1983, Discovery fossil lobster from the Kuechulin Formation (Miocene): Southern Taiwan, 26, 129-136.

Hu, C. H., Tao, H. J., 1996, Crustacean fossils of Taiwan: Taipei, Ta-Jen Printers, 228p.

Hyžný, M., Schlögl, J., 2011, An early Miocene deep-water decapod crustacean faunule from the Vienna Basin (Western Carpathians, Slovakia): Palaeontology, 54(2), 323-349. https://doi. org/10.1111/j.1475-4983.2011.01033.x

Japan Agency for Marine-Earth Science and Technology (JAMSTEC), 1999, Shinkai 2000 dive 1135, Dataset retrieved from http:// www.godac.jamstec.go.jp/jedi/static_ player/e/2K1135CCDDB10_00445600

Jenkins, M. F., 1972, Metanephrops, a new genus of Late Pliocene to Recent lobsters (Decapoda, Nephropdidae): Crustaceana, 22, 161-177. https://doi.org/10.1163/156854072x00426

Kováč, M., Andreyeva-Grigorovich, A., Bajraktarević, Z., Brzobohatý, R., Filipescu, S., Fodor, L., Harzhauser, M., Nagymarosy, A., Oszczypko, N., Pavelić, D., Rögl, F., Saftić, B., Sliva, U., Studencka, B., 2007,
Badenian evolution of the Central Paratethys Sea: paleogeography, climate and eustatic sea-level changes: Geologica Carpathica, 58(6), 579-606.

Kováč, M., Halásová, E., Hudáčková, N., Holcová, K., Hyžný, M., Jamrich, M., Ruman, A., 2018, Towards better correlation of the Central Paratethys regional time scale with the standard geological time scale of the Miocene Epoch: Geologica Carpathica, 69(3), 283-300. https://doi.org/10.1515/ geoca-2018-0017

Latreille, P. A., 1802, Histoire naturelle, générale et particulière des Crustacés et des Insectes. Ouvrage faisant suite aux OEuvres de Leclerc de Buffon, et partie du Cours complet d'Histoire naturelle rédigé par C.S. Sonnini, membre de plusieurs Sociétés savantes: Familles naturelles des genres, 3, 1-467. https://doi.org/10.5962/bhl.title.15764

Leach, W. E., 1814, Crustaceology: Brewster's Edinburgh Encyclopedia, 7, 383-437.

Lohmann, G.P., Carlson J.J., 1981, Oceanographic significance of Pacific late Miocene calcareous nannoplankton: Marine Micropaleontology, 6(5-6), 553-579. https:// doi.org/10.1016/0377-8398(81)90021-9

Martini, E., 1971, Standard Tertiary and Quaternary calcareous nannoplankton zonation. Proceedings of the II Planktonic Conference: Tecnoscienza, Roma, 739-785.

Mertin, H., 1941, Decapode Krebse aus dem subhercynen und Braunschweiger Emscher und Untersenon sowie Bemerkungen über einige verwandte Formen in der Oberkreide: Nova Acta Leopoldina, 10, 1-264.

Mikuž, V., Gašparič, R. 2014, Nekaj redkih fosilov iz Slovenskih goric, (Some rare fossils from Slovenske gorice, Slovenia): Geologija, 57 (2), 155-166. https://doi.org/10.5474/ geologija.2014.013

Okada, H., McIntyre, A., 1979, Seasonal distribution of the modern coccolithophores in the western North Atlantic Ocean: Marine Biology, 54(4), 319-328. https://doi. org/10.1007/bf00395438 
Pavšič, J., Horvat, A., 2009, Eocene, Oligocene and Miocene in Central and Eastern Slovenia. in Pleničar, M. (ed.), The Geology of Slovenia: Geološki zavod Slovenije, 373-426.

Placer, L., 1999, Contribution to the macrotectonic subdivision of the border region between Southern Alps and External Dinarides: Geologija, 41, 223-255. https:// doi.org/10.5474/geologija.1998.013

Rifelj, H., Jelen, B., 2001, Do the Karpatian and Badenian microforaminiferal faunas of Slovenia reflect global climatic and tectonic changes?: Geološki zbornik, 16, 34-41.

Rijavec, L., 1976, Biostratigrafija miocena v Slovenskih goricah, (Biostratigraphy of Miocene Beds from Slovenske Gorice): Geologija, 19, 53-79.

Rijavec, L., 1978, Tortonska in sarmatska mikrofavna $\mathrm{v}$ zahodnem delu Slovenskih goric, (Tortonian and Sarmatian microfauna from the Western Slovenske Gorice hills): Geologija, 21(2), 209-238.

Rögl, F., 1998, Paratethys Oligocene-Miocene stratigraphic correlation, in Cicha, I., Rögl, F., Rupp, C., Ctyroka, J. (eds.), Oligocene - Miocene foraminifera of the Central Paratethys: Abhandlungen der Senckenbergischen Naturforschenden Gesellschaft, 549, 3-7.

Rögl, F., 1999, Mediterranean and Paratethys, facts and hypotheses of an Oligocene to Miocene paleogeography: Geologica Carpathica, 59, 339-349.

Tapparone Canefri, C., 1873, Intorno ad una nuova specie di Nephrops, genera di Crostacei Decapodi Macruri: Memorie della Realle Accademia delle Scienze di Torino, 28, 325-329.
Theodoridis, S., 1984, Calcareous nannofossil biostratigraphy of the Miocene and revision of the helicoliths and discoasters: Utrecht Micropaleontological Bulletin, 32, 1-271.

Tshudy, D. M., 2003, Clawed lobster (Nephropidae) diversity through time: Journal of Crustacean Biology, 23, 178-186. https://doi. org/10.1651/0278-0372(2003)023 [0178:cln $\mathrm{dtt}] 2.0 . \mathrm{co} ; 2$

Tshudy, D., Chan, T. Y., 2014, Taxonomic note: the fossil clawed lobster, Metanephrops elongatus $\mathrm{Hu}$ and Tao, 2000 (Nephropidae), is a nomen dubium but definitely not a Metanephrops: Zootaxa, 3760(3), 494-496. https://doi. org/10.11646/zootaxa.3760.3.17

Tshudy, D., Chan, T. Y., Sorhannus, U., 2007, Morphology Based Cladistic Analysis of Metanephrops: The Most Diverse Extant Genus of Clawed Lobster (Nephropidae): Journal of Crustacean Biology, 27(3), 463476. https://doi.org/10.1651/s-2777.1

Tshudy, D., Sorhannus, U., 2000, Pectinate Claws in Decapod Crustaceans: Convergence in four Lineages: Journal of Paleontology, 74(3), 474-486. https://doi.org/10.1017/ s0022336000031735

Winter, A., Jordan, R., Roth, P., 1994, Biogeography of living coccolithophores in ocean waters, in Winter, A., Siesser, W. (eds.), Coccolithophores: Cambridge University Press, Cambridge, 13-37.

Young, J., R., 1998, Neogene, in Bown, P., R. (ed.), Calcareous Nannofossil Biostratigraphy: British Micropalaeontological Society Publication Series. 225-265. https://doi. org/10.1007/978-94-011-4902-0_8

Žnidarčič, M., Mioč, P., 1989, Lista Maribor in Leibnitz. Osnovna geološka karta SFRJ, 1:100000: Zvezni geološki zavod, Beograd. 